\title{
Description of the long-term ozone data series obtained from different instrumental techniques at a single location: the Observatoire de Haute-Provence $\left(43.9^{\circ} \mathrm{N}, 5.7^{\circ} \mathrm{E}\right)$
}

\author{
M. Guirlet ${ }^{1}$, P. Keckhut ${ }^{2}$, S. Godin ${ }^{2}$, G. Mégie ${ }^{2}$ \\ ${ }^{1}$ Now at: European Ozone Research Coordinating Unit, Centre for Atmospheric Science, University of Cambridge, \\ 14 Union Road, Cambridge CB2 1HE, England \\ ${ }^{2}$ Service d'Aéronomie CNRS, Institut Pierre Simon Laplace, Université Pierre et Marie Curie, Boite 102, 4 place Jussieu, \\ F-75252 Paris Cedex, France
}

Received: 20 September 1999 / Revised: 10 April 2000 / Accepted: 5 June 2000

\begin{abstract}
A description of the long-term data series of stratospheric ozone at the Observatoire de HauteProvence is presented. At this station, data sets with temporal length of a decade or more are provided in the framework of the Network for Detection of Stratospheric Change by ground-based experiments: Dobson spectrophotometer (in both column and Umkehr mode), lidar and ozonesondes. The data time series obtained from these various instruments operated simultaneously at a single site and complemented by SAGE II spaceborne measurements are first described with respect to instrumental uncertainties, sampling rate and time evolution. These data series are then compared to each other in terms of sampling rate and average vertical profiles. The difference between the mean ozone profiles of the data sets can partly be explained by the different sampling rate of the instruments. Using the overlap and the complementarity of the various data sets, a preliminary estimate of the long-term evolution of ozone over the last decade over Southern France is conducted. Trend values for both total column and vertical profiles are derived using the multi-regression statistical model AMOUNTS $\mathrm{O}_{3}$. In the $25-40 \mathrm{~km}$ altitude range, a similar ozone decrease from $-4 \%$ /decade to $-10 \%$ / decade is observed from lidar, Umkehr and SAGE II data series in good agreement with previous estimates. In the lower stratosphere $(15-25 \mathrm{~km})$, large negative trends in the ozone vertical profile are observed. In addition, the negative trend of $-5.4 \% /$ decade in total ozone inferred from the Dobson measurements over the period 1983-1995 is in good agreement with the integrated trend profile.
\end{abstract}

Key words: Atmospheric composition and structure (evolution of the atmosphere; middle atmosphere composition and chemistry; instruments and techniques)

Correspondence to: M. Guirlet

\section{Introduction}

Satellite and ground-based measurements have demonstrated that ozone depletion has been occurring for almost two decades on a global scale [Stolarski et al., 1992; Gleason et al., 1993; World Meteorological Organization (WMO), 1994, 1998]. Of particular interest are the trends observed in the northern hemisphere midlatitudes which occur over highly populated areas. Ozone trends inferred from the longest total ozone series available, Dobson measurements at Arosa $\left(47^{\circ} \mathrm{N}\right)$ between 1926 and 1996, reach $-2.3 \% \pm 0.6 \%$ /decade (Staehelin et al., 1998). Analysis of the long-term series of ozone profiles reveals that the largest decrease is observed in the lower stratosphere. It reaches $-8 \%$ / decade at $15 \mathrm{~km},-2 \%$ /decade at $30 \mathrm{~km}$ and $-7 \%$ / decade at $40 \mathrm{~km}$ for measurements over northern midlatitudes between 1980-1996 (SPARC-IOC, 1998). Though the understanding of the chemical, dynamical and radiative processes leading to those trends has been greatly improved (WMO, 1998), it is still difficult to accurately quantify the natural variability and the ozone trends as a function of altitude, as each experimental technique presents some specific instrumental uncertainties (SPARC-IOC, 1998). Only a few comparisons of ground-based data sets measuring at the same location, continuously over a long time period, are available, as experiments rarely operate at the same site. At the Observatoire de Haute-Provence (OHP, $\left.43.9^{\circ} \mathrm{N}, 5.7^{\circ} \mathrm{E}\right)$, several instruments (Dobson, lidar and ozonesondes) have been operating routinely for more than a decade, providing independent measurements of total ozone content and vertical profile. The combination of these existing data sets offers an unique opportunity to compare different techniques and to validate the concept of a multi-instrument monitoring station as proposed by the Network for Detection of Stratospheric Change (NDSC). In this paper, we present an extensive comparison of the different ozone data sets obtained at OHP in the framework of the NDSC. This will allow to assess 
the reliability of such measurements before they are made available to the full scientific community in the near future. Long-term changes will also be investigated as they bring additional information on the complementarities and the capabilities of the different instruments operated at OHP to insure a long-term geophysical monitoring free of any instrumental drift. Section 2 is devoted to the description of the observational methodologies used for the ozone measurements at OHP: lidar, ozonesondes, Dobson, Umkehr and the satellite borne instrument SAGE (Stratospheric Aerosol and Gas Experiment) II. All the data sets will be limited to the end of 1995, to take into account the limits of validity of some of them. In Sect. 3, the main characteristics of the database of ozone vertical profiles available at the station are discussed, based on several intercomparison studies between the different data sets. The analysis used to quantify the long-term evolution of the ozone total content and vertical profile is presented in Sect. 4. Finally, although the time lengths of some of the databases are still short, preliminary results on trends in the ozone vertical profile are presented together with a first quantitative estimate of the impact of the 11-year solar cycle and the volcanic aerosols on the ozone changes.

\section{Instruments and data at $\mathrm{OHP}$}

The Observatoire de Haute-Provence is located in southern France $\left(43.9^{\circ} \mathrm{N}, 5.7^{\circ} \mathrm{E}\right)$. Measurements have been made there regularly for more than 15 years and have already been widely used for the study of ozone and temperature variability and for various satellite validation (Pelon and Mégie, 1982; Pelon et al., 1986; de La Noë et al., 1987; Pommereau and Goutail, 1988; Attmannspacher et al., 1989; Hauchecorne et al., 1991; Lacoste, 1994; Keckhut et al., 1995; Guirlet, 1997). Since 1991, the station has been part of the Primary Alpine station of the NDSC [Network for Detection of Stratospheric Change, (Kurylo and Solomon, 1990)] and is representative of the northern hemisphere midlatitudes. The coordination with other European complementary stations of the NDSC (intercomparison of experimental techniques, validation of measurements) has been mainly performed in the frame of the EC project ESMOS (European Stratospheric Monitoring Stations) (Simon et al., 1997).

\subsection{Presentation of the instruments}

2.1.1 Dobson and SAOZ instruments. Total ozone measurements have been performed routinely at OHP since September 1983 (Table 1) using a Dobson spectrophotometer as part of the Automated Dobson Network (Komhyr et al., 1989). The method is described in detail in Dobson $(1931,1957)$. The aerosol effect is estimated to be lower than $1 \%$ to $2 \%$ in aerosol background conditions (WMO, 1988). The errors due to Mount Pinatubo aerosols do not exceed $\pm 1 \%$ (WMO, 1994). The precision of the long-term ozone measurement for annual means is estimated to be $\pm 1 \%$ (WMO, 1988). The accuracy is strongly dependent on the quality of the calibration of the instrument and of its operation (WMO, 1988). Several intercomparison campaigns (Arosa, 1990; Hradec Kralove, 1993; Izana, 1994) allowed to produce a high quality long-term total ozone record at OHP (WMO, 1994), and one can thus consider that the Dobson data are reliable measurements for the detection of a long-term evolution of total ozone.

Total ozone measurements are also provided at OHP by the UV-visible SAOZ spectrometer since June 1992 (Pommereau and Goutail, 1988). Due to the short time length of the record, we will use in the frame of this study only the total ozone data provided by the Dobson spectrophotometer.

2.1.2 Ozonesondes. Since the beginning of the ozonesonde measurements at OHP, many instrumental changes have been made. The most important one is the change in the type of sondes in 1991. The Brewer-Mast sonde was used from October 1984 until April 1991 and the operation of ECC sonde started in January 1991 and was continued until now (Table 1). With the shift of type of sondes, the number of profiles per year increased stepwise in 1991. The altitude range of the measurements is between the ground and about $25 \mathrm{~km}$ to $30 \mathrm{~km}$ altitude. The vertical resolution is about $200 \mathrm{~m}$. The instrumentation method, the operating procedure and the main errors of the measurement are detailed in previous papers (Beekmann et al., 1994; Komhyr et al.,
Table 1. Time period for routine operation of ozone measurements and total number of measurements according to the various instruments operated at OHP. The time periods during which the lidar and SAGE II at lower altitudes and the Umkehr profiles are not useable for trend studies, are reported in the last column (see text)

\begin{tabular}{llcl}
\hline Experiment & Period & Number & $\begin{array}{l}\text { Period of data not } \\
\text { available for trend studies }\end{array}$ \\
\hline Dobson & $09 / 83-12 / 95$ & 2876 & $\emptyset$ \\
Umkehr & $09 / 83-12 / 95$ & 1107 & $09 / 91-06 / 93$ \\
Ozonosondes & $10 / 84-12 / 95$ & 280 & $\emptyset$ \\
Brewer-Mast & $10 / 84-04 / 91$ & & $\emptyset$ \\
ECC & $01 / 91-12 / 95$ & & $\emptyset$ \\
Lidar & $10 / 86-12 / 95$ & 605 & $08 / 91-06 / 93$ \\
Rayleigh channels only & $10 / 86-12 / 93$ & & $08 / 91-06 / 93$ \\
Rayleigh and Raman channels & $01 / 94-12 / 95$ & & $\emptyset$ \\
SAGE II & $10 / 84-12 / 95$ & 1097 & $12 / 91-06 / 93$ \\
\hline
\end{tabular}


1995; Ancellet and Beekmann, 1997; Vialle, 1997). The precision of the Brewer sonde ranges from about \pm 10 to $\pm 15 \%$, while the ECC sonde has a better precision of about $\pm 5 \%$. Their accuracy is between \pm 10 and $\pm 20 \%$ (Smit and Kley 1998). The precision of the stratospheric measurements is improved by normalizing the sonde profile to the total ozone measured by the Dobson spectrometer (WMO, 1982). This normalization reduces the bias between the Brewer-Mast measurements and the ECC measurements at altitude levels lower than $23 \mathrm{~km}$, and intercomparison campaigns showed a negative bias of $-5 \%$ between ECC and Brewer-Mast sondes if this correction factor is applied (Hilsenrath et al., 1986; Beekmann et al., 1994). This bias is taken into account in the present study.

2.1.3 Lidar instrument. Lidar measurements of the ozone vertical distribution between about 18 and $45 \mathrm{~km}$ have been performed routinely at OHP since October 1986 (Table 1). The measurement technique is based on the DIAL (Differential Absorption Laser) technique and detailed in Pelon and Mégie (1982), Mégie et al. (1985), Pelon et al. (1986), Godin (1987), Godin et al. (1989). In presence of high aerosol loading, the ozone profile retrieved from the Rayleigh signals is locally perturbed at the altitude of the aerosol cloud. Thus, after the Mount Pinatubo eruption in June 1991, the lidar ozone profiles were available only above the volcanic cloud, so that the minimum altitude of the measurements gradually decreased from $30 \mathrm{~km}$ in December 1991 to $20 \mathrm{~km}$ in the second part of 1993 .

There were several changes on the instrumental configuration between 1986 and 1994 to improve the quality of the measurements. The main one was the implementation of new optical and electronic detecting systems on the ozone lidar experimental set-up at the beginning of 1994. Two so-called "Rayleigh" profiles corresponding to the atmospheric elastic scattering provide an ozone profile between 18 and $45 \mathrm{~km}$. Another so-called "Raman" profile obtained simultaneously from the first Stokes vibrational Raman scattering of the emitted wavelengths by molecular nitrogen (McGee et al., 1993) provides an ozone profile unperturbed by the aerosols, between the tropopause and $25 \mathrm{~km}$. The final ozone profile is then computed from the combination of the "Raman" and the "Rayleigh" profiles. This improvement of the lidar system led to a substantial increase of the number of profiles per year (from about 40 in 1987 to about 100 in 1995).

The vertical resolution of the ozone profile is altitude dependent. Since 1994, the vertical resolution is about $1.5 \mathrm{~km}$ at $15 \mathrm{~km}$ ("Raman" profile). It increases to $0.5 \mathrm{~km}$ at $20 \mathrm{~km}$ ("Rayleigh" profile), decreasing up to $2 \mathrm{~km}$ at $30 \mathrm{~km}$ and $4 \mathrm{~km}$ at $40 \mathrm{~km}$.

The accuracy of the ozone lidar measurements is estimated to be about $\pm 3 \%$ in the case of background aerosol loading (Godin et al., 1989). The precision of the measurement decreases from about $\pm 2 \%$ below $20 \mathrm{~km}$ to more than $\pm 10 \%$ above $40 \mathrm{~km}$ (Godin et al., 2000). The improvement of the signal to noise ratio over time may have induced a time dependent bias in the upper part of the profile. In terms of trends assessment, and because of the lack of measurements after the Mount Pinatubo eruption due to aerosol contamination, the lidar measurements could not be used below $25 \mathrm{~km}$ as the record was interrupted between 1991 and 1993 (Table 1). Above $40 \mathrm{~km}$, the precision of the measurements during the first years of the record may be too low to detect a reliable trend. Therefore, use of lidar measurements for trends assessment over the period 1984-1995 will be restricted to the altitude range 25$40 \mathrm{~km}$, complementing the ozonesonde records at higher altitude.

2.1.4 Umkehr method. The Umkehr measurements have been made routinely at OHP since September 1983 (Table 1). Ozone partial pressure is obtained in 12 atmospheric adjacent layers, of $5 \mathrm{~km}$ width each, between the ground and the $60 \mathrm{~km}$ altitude level (Götz et al., 1934; Mateer and DeLuisi, 1992; SPARC-IOC, 1998). The vertical resolution of the Umkehr measurements is equal to $12.5 \mathrm{~km}$ (WMO, 1988). The measurement errors are about $10 \%$ in layers 4 through 8 which correspond to the only layers where independent information could be retrieved (WMO, 1988). The partial pressure in each layer is further converted to ozone concentration using the National Centre for Environmental Prediction (NCEP).

The Umkehr measurements are perturbed by stratospheric aerosols which induce a negative bias in the ozone partial pressures derived in the stratosphere. A first estimate of the aerosol effect on the Umkehr measurements according to the optical depth has been derived from about 2000 SAGE II/Umkehr intercomparisons (Newchurch and Cunnold, 1994; Newchurch et al., 1995). We have used in this study aerosolcorrected data provided by M. Newchurch (private communication). Because of the large error of the measurements due to the volcanic cloud after the Mount Pinatubo eruption, no data is available at OHP between September 1991 and June 1993.

Due to this lack of measurements for about two years, the Umkehr measurements may not give very reliable values of the ozone trend at the OHP in the lower stratosphere.

2.1.5 Satellite instruments. SAGE II. The satellite experiment SAGE II was launched on the ERBS satellite and has provided ozone profiles since October 1984 (Table 1) by measurement in the solar occultation mode. Details on the measurement method are given in previous papers (Chu and McCormick, 1979; WMO, 1988; Chu et al., 1989; SPARC-IOC, 1998). The version of the data used here is version 5.93 which was the last public version of the data available at the time of this study.

The vertical resolution is about $1 \mathrm{~km}$. For the time periods without high stratospheric aerosol load, the statistical error is larger than $\pm 10 \%$ for the altitude levels lower than $15 \mathrm{~km}$. It ranges from \pm 5 to $\pm 10 \%$ between 15 and $20 \mathrm{~km}$, is equal to $\pm 5 \%$ between 24 and $45 \mathrm{~km}$, and increases above until the upper altitude of 
the vertical profile (Attmanspacher et al., 1989; Cunnold et al., 1989; Newchurch et al., 1995). For the altitudes lower than $12 \mathrm{~km}$, the uncertainties on the ozone measurements become very large (up to $15 \%$ ) because of the low ozone quantities and the large aerosol correction which is required, due to the aerosol interference in the ozone spectral channel at $600 \mathrm{~nm}$.

No ozone value is available at the altitude levels of the volcanic aerosol layer after the Mount Pinatubo eruption due to the high contamination of the $600 \mathrm{~nm}$ channel by the volcanic aerosols (Table 1). Thus, the SAGE II measurements should be useful for the detection of the ozone trend mainly in the upper stratosphere.

In order to compare the ground-based measurements and the satellite measurements, for each available day, the selected SAGE II ozone profile corresponds to the closest profile to the OHP station, within a radius of $1000 \mathrm{~km}$. The SAGE II data have been chosen for this evaluation because they provide the best vertical resolution comparable with the lidar one. For instance, the SBUV measurements have a much lower vertical resolution than the SAGE II measurements (WMO, 1994; SPARC-IOC, 1998) and are also sensitive to the presence of aerosols (McPeters et al., 1994).

TOMS. The Nimbus 7 TOMS provides total ozone measurements on nearly every day from November 1978 until May 1993 (Stolarski et al., 1991; Gleason et al., 1993). The TOMS measurements are used mainly for validation purposes. We use in this study version 6.0 of the TOMS data. Some previous studies showed that trends derived from version 7 TOMS data (McPeters et al., 1996) are very similar (within \pm 1 to $2 \%$ per decade) to the ones derived from the earlier version 6 data (Stolarski et al., 1991, 1992).

\subsection{Instrument time series}

Due to the differences between the technical constraints of each experiment, the ozone databases available at OHP are heterogeneous. As previously outlined, the vertical resolution and the uncertainties on the ozone measurements are very different according to the type of experiment. The same comment also applies to the sampling rate which shows large variations as a function of time, and according to the type of experiment.

2.2.1 Sampling rate. As the ozone trends have been shown to be seasonally dependent (Stolarski et al., 1991; WMO, 1994; Bojkov and Fioletov, 1995; Chandra et al., 1996; Harris et al., 1997), the sampling rate throughout the year should be as uniform as possible. Indeed, differences in the long-term sampling between the various instruments operated at OHP could result from the different observation conditions required for each instrument. For example, the sampling throughout the year for the Umkehr, Dobson and ozonesonde measurements is rather regular, and the variation of the number of measurements per month does not exceed $35 \%$. On the contrary, there is a larger variation in the monthly number of lidar measurements (Fig. 1). This number is lower in May and in September (for the second part of the year) over the whole period of measurements. This can be related to the frequent cloudy skies observed during these months over OHP, preventing lidar operation, as this requires clear sky conditions.

Similarly, a large variation is also observed in the monthly number of SAGE II measurements with lower values during the summer months, particularly in August (Fig. 1). This is merely due to the variation in the satellite orbit which overpasses the northern midlatitudes more frequently in winter than in summer (Cunnold et al., 1989).

Beyond a given limit of several measurements per week, the increase in the sampling rate of the measurements does not bring increased confidence for trend estimates, as soon as two successive measurements are not independent with reference to the ozone field

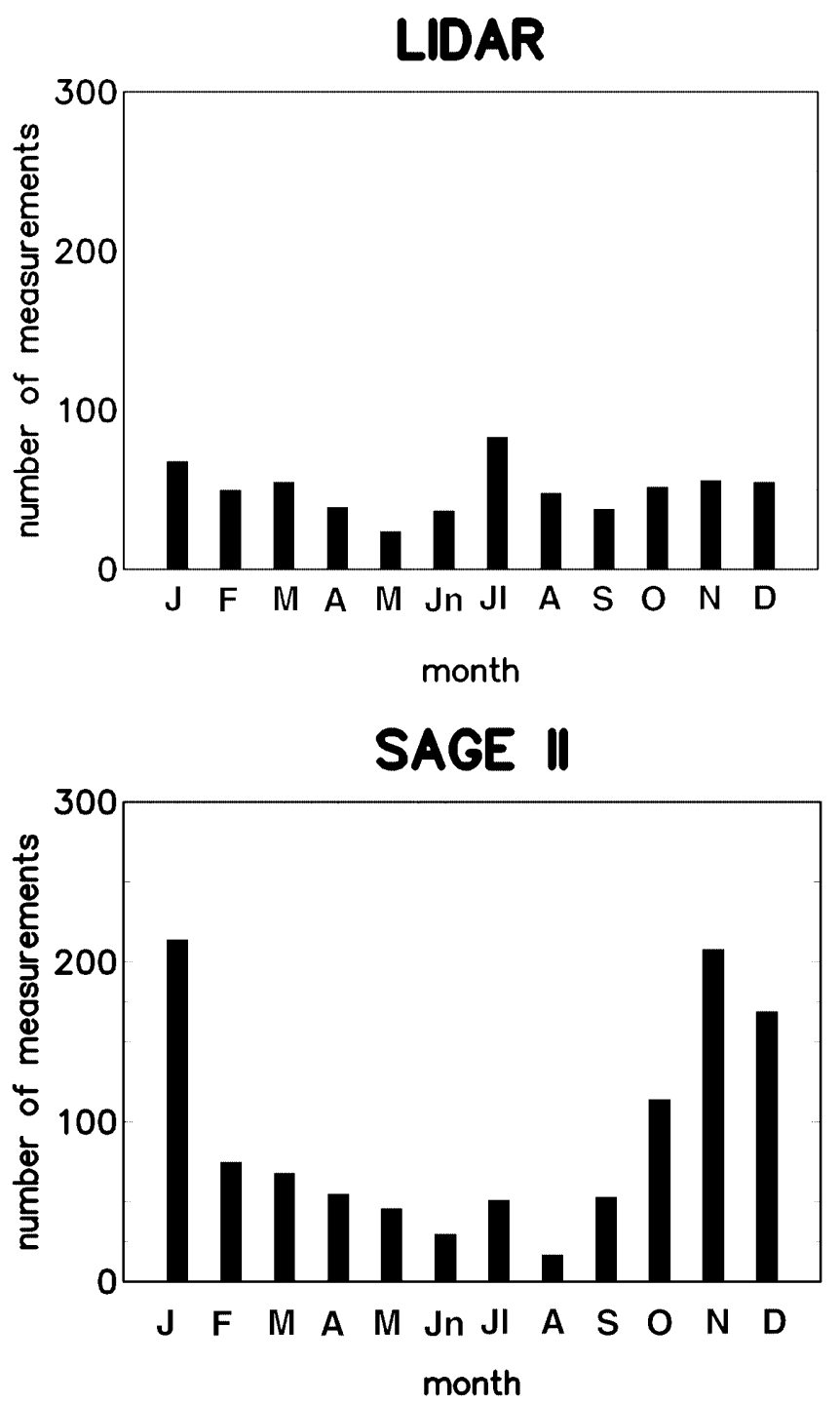

Fig. 1. Total number of measurements per month for lidar measurements between 1986 and 1995 (upper panel) and for SAGE II measurements between 1984 and 1995 (lower panel) at OHP 
variability due to the frequency of geophysical processes sampled at OHP. This degree of dependence between two successive measurements is given by the autocorrelation (see Appendix A). However, such measurements can be averaged to reduce uncertainty in the natural variability, which in turn impacts the confidence level in the trend assessment. Considering the data sampling available from measurements at OHP and the autocorrelation of two successive measurements, the best compromise between the dependence of successive measurements and the reduction of the uncertainty is obtained by monthly averaging of the data. In this study, monthly means have been considered for all data series.

2.2.2 Altitude dependence of the number of measurements. Due to the evolution of the characteristics of the instruments and to the varying observation conditions as reported previously, the total number of available measurements can also be altitude dependent. This altitude dependence is illustrated by the variation of the percentage ratio between the number of monthly means available for each instrument and the total number of months over the whole period (Fig. 2). This ratio is uniform in all layers and close to $80 \%$ for the Umkehr measurements. For the SAGE II and the lidar measurements, the ratio is lower at the altitude levels below $25 \mathrm{~km}$, due to the perturbation in the lower stratosphere by the high aerosol loading after the eruption of Mount Pinatubo. At the altitude levels higher than $40 \mathrm{~km}$, the number of lidar measurements available is also decreasing due to experimental limitations, likewise the number of ozonesonde measurements above $25 \mathrm{~km}$. This ratio is only indicative and should be considered carefully, as even for the higher values close to $70-80 \%$, it does not preclude that large temporal gaps could exist in the data record (see Sect. 2.1).

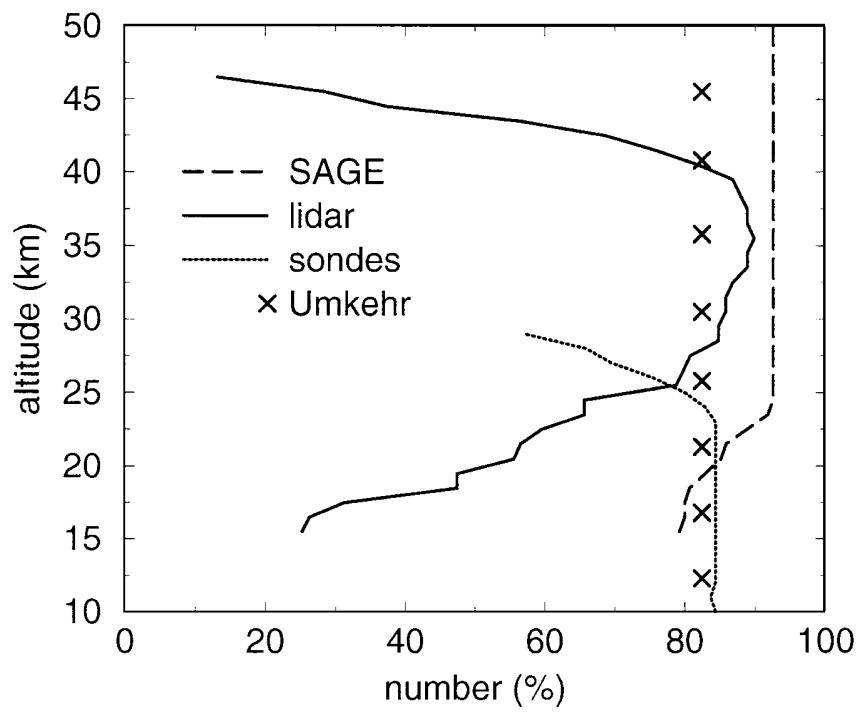

Fig. 2. Altitude dependence of the percentage ratio between the number of monthly means available for each instrument and the total number of months over the whole period considered in this study (see Table 1)

\section{Long-term data intercomparison}

In this section, we will compare the ozone mean values by the different instruments. This comparison may highlight possible biases of instrumental origin between the different techniques. Such bias is often associated with the instrumental configuration and thus may change with the successive improvements of the instruments, inducing drift and artificial trends. Thus, its quantification would be of prime importance for the assessment of long-term data set continuity. In a second part, the main characteristics of the ozone seasonal variability as recorded by the various instruments will be compared, further to check the consistency of the data sets, and the ability of the different techniques to record atmospheric variability on a monthly basis.

Comparisons of instruments at OHP have been made at several occasions in the frame of the NDSC (Godin, 1987; Beekmann et al., 1994; Mc Gee et al., 1994; WMO, 1994; Smit et al., 1998). Although such campaigns are of prime importance for instrument validation, they can efficiently be complemented by continuous comparisons on longer time scales between collocated instruments. This is achieved in this paper by comparing the average ozone values obtained from the different instruments during the time periods given in Table 1.

The mean difference between TOMS and Dobson measurements at OHP over the period 1983-1993 is equal to $3.4 \pm 2.7 \mathrm{DU}$. This difference might be due to the slight difference of location between TOMS and Dobson measurements.

The differences between the average vertical ozone profiles obtained from lidar, SAGE II, ozonesonde and Umkehr measurements (Fig. 3) are not significant at the $1 \sigma$ level, and one can note the good agreement between Umkehr and the values derived from other instruments, throughout the whole altitude range, despite the coarse resolution of these measurements.

However, differences can still be observed and related to the operating mode and characteristics of the instruments. Below $25 \mathrm{~km}$ altitude, the average profile derived from the SAGE II measurements shows higher mean values than the average profiles of the groundbased experiments. The values of the relative difference between lidar and SAGE II measurements [(lidar-SAGE II)/SAGE II in \%] varies from $-21.2 \%$ at $15 \mathrm{~km}$ to $-0.2 \%$ at $25 \mathrm{~km}$ and remains then roughly constant up to $42 \mathrm{~km}$ (Fig. 4), before increasing rapidly to large positive values up to $50 \mathrm{~km}$. Similarly, the values of the relative difference between ozonesonde and SAGE II measurements [(ozonesonde-SAGE II)/SAGE II in \%] extend from $-13.6 \%$ at $15 \mathrm{~km}$ to $1.0 \%$ at $25 \mathrm{~km}$. When the differences between the mean profiles are calculated only with the measurements in time coincidence (measurement times not different from more than $24 \mathrm{~h}$, Fig. 5), one can first observe that the amplitude of the differences between ozonesonde and SAGE II measurements is greatly reduced between 20 and $30 \mathrm{~km}$, independently of the sign of the bias previously observed. This certainly emphasizes the effect of the 

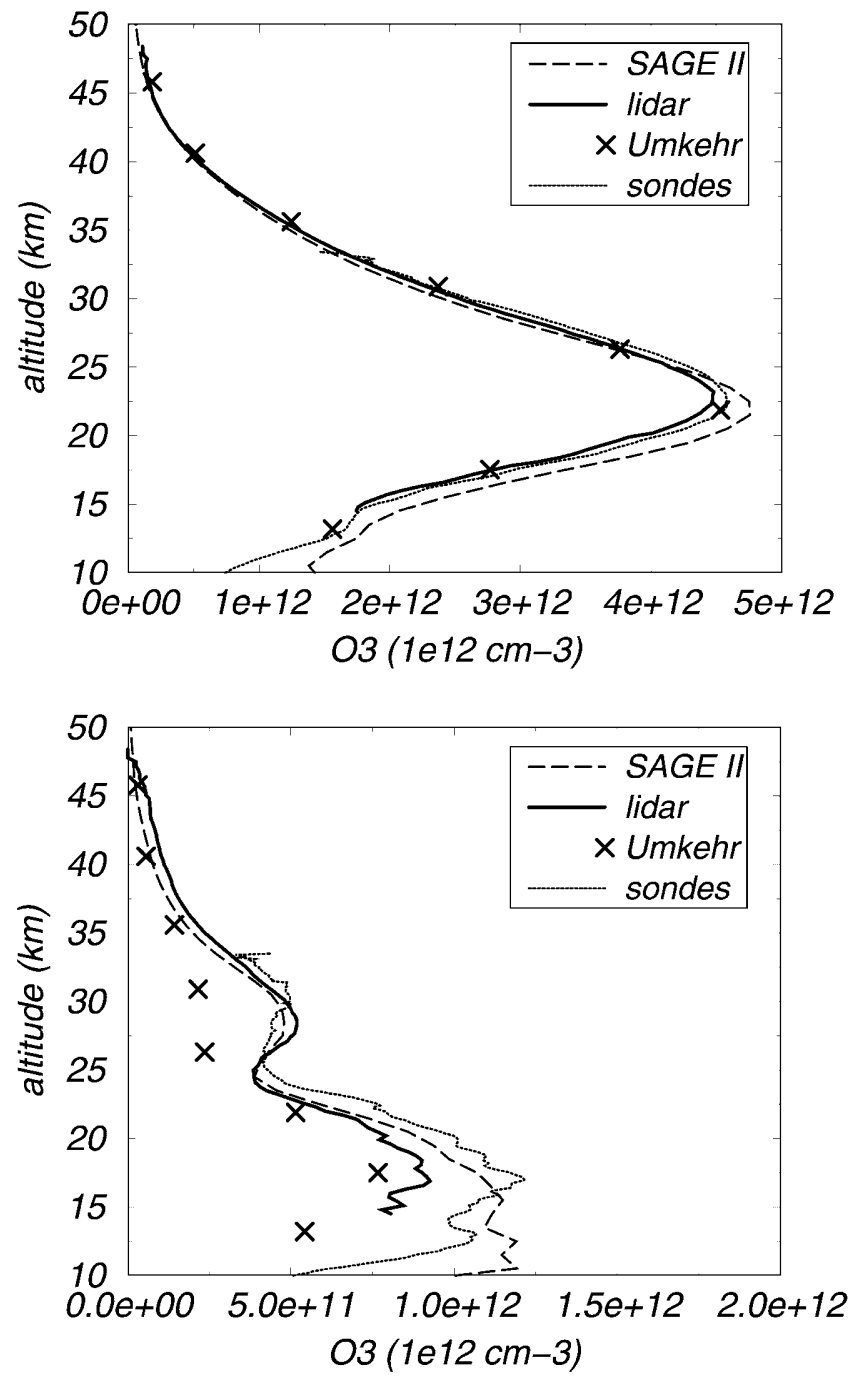

Fig. 3. Mean vertical ozone profiles (top) and corresponding standard deviation $(1 \sigma)$ (bottom) between $10 \mathrm{~km}$ and $50 \mathrm{~km}$ for SAGE II, lidar, ozonosondes and Umkehr measurements at OHP

sampling rate especially for measurements such as the ozonesondes which are performed at a rather low sampling rate. Whereas large positive values of the difference between lidar and SAGE II measurements are still observed in the upper altitude range, the agreement is better than $1 \%$ from 25 to $40 \mathrm{~km}$ when only measurements in time coincidence are considered. The maximum relative difference above $25 \mathrm{~km}$ altitude is then equal to $-0.7 \%$ at $32 \mathrm{~km}$ as compared to $6.6 \%$ when using the whole data set. However, at the altitude levels lower than $25 \mathrm{~km}$, the differences between SAGE II and lidar measurements are still largely negative reaching $-14.2 \%$ at $15 \mathrm{~km}$. And the difference between SAGE II and ozonesonde measurements reaches even larger values after selection of time coincident data $(-18.9 \%$ instead of $-13.6 \%$ at $15 \mathrm{~km})$. This overestimation of the ozone values below $25 \mathrm{~km}$ by the SAGE II instrument as compared to ground-based instruments is probably due to an insufficient correction of the aerosolinduced effect on the SAGE II derived ozone concen-
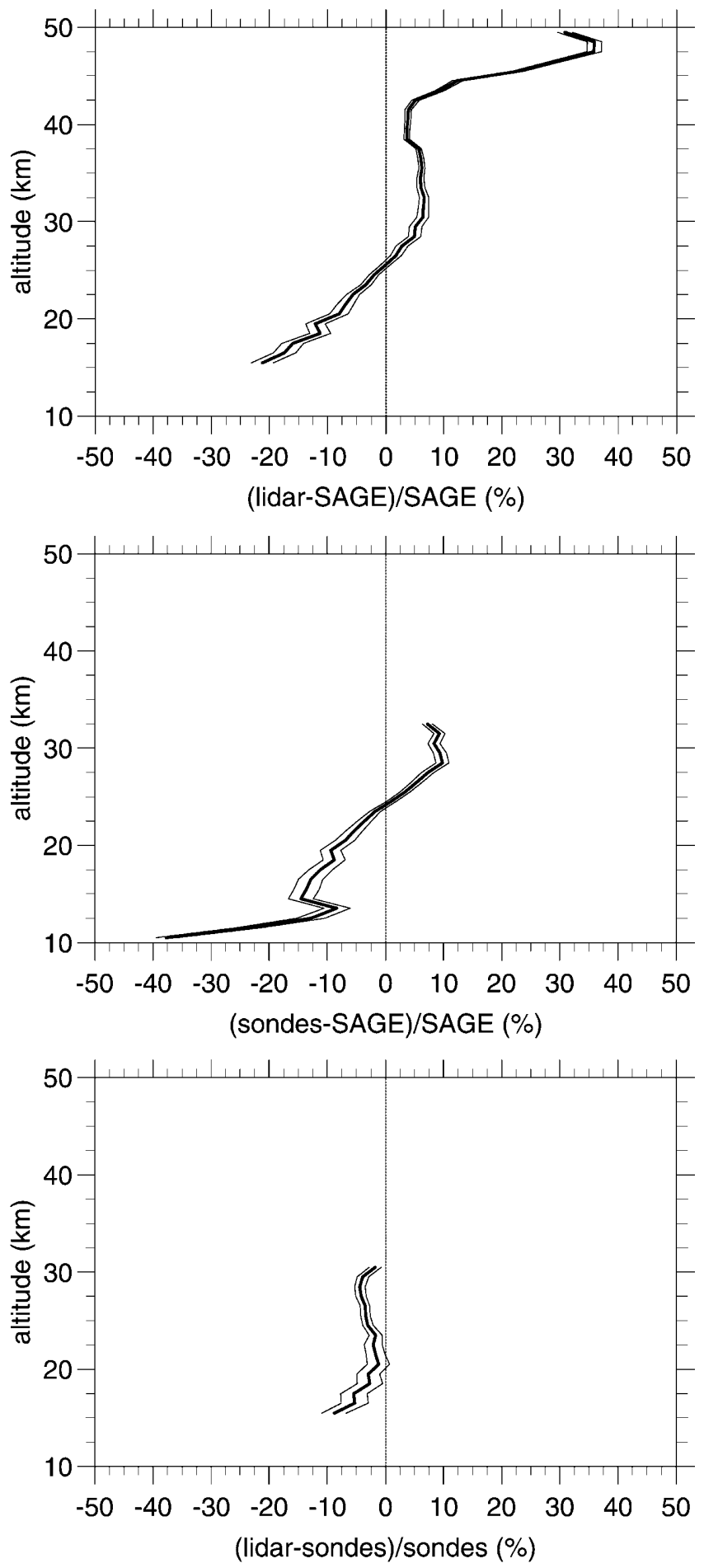

Fig. 4. Altitude dependence of the relative difference between the mean vertical profiles of lidar and SAGE II measurements between $10 \mathrm{~km}$ and $50 \mathrm{~km}$ plotted with the two $\sigma$ standard deviation limits (top); same figure for ozonesonde and SAGE II measurements (middle); same figure for lidar and ozonesonde measurements (bottom)

trations at lower altitudes (Cunnold et al., 1996). The use of the SAGE II version 5.96 data which were not available at the time of this study, might lead to an improvement to this problem (SPARC-IOC, 1998).

The values of the relative difference between lidar and ozonesonde measurements [(lidar-sonde)/sonde in \%] 

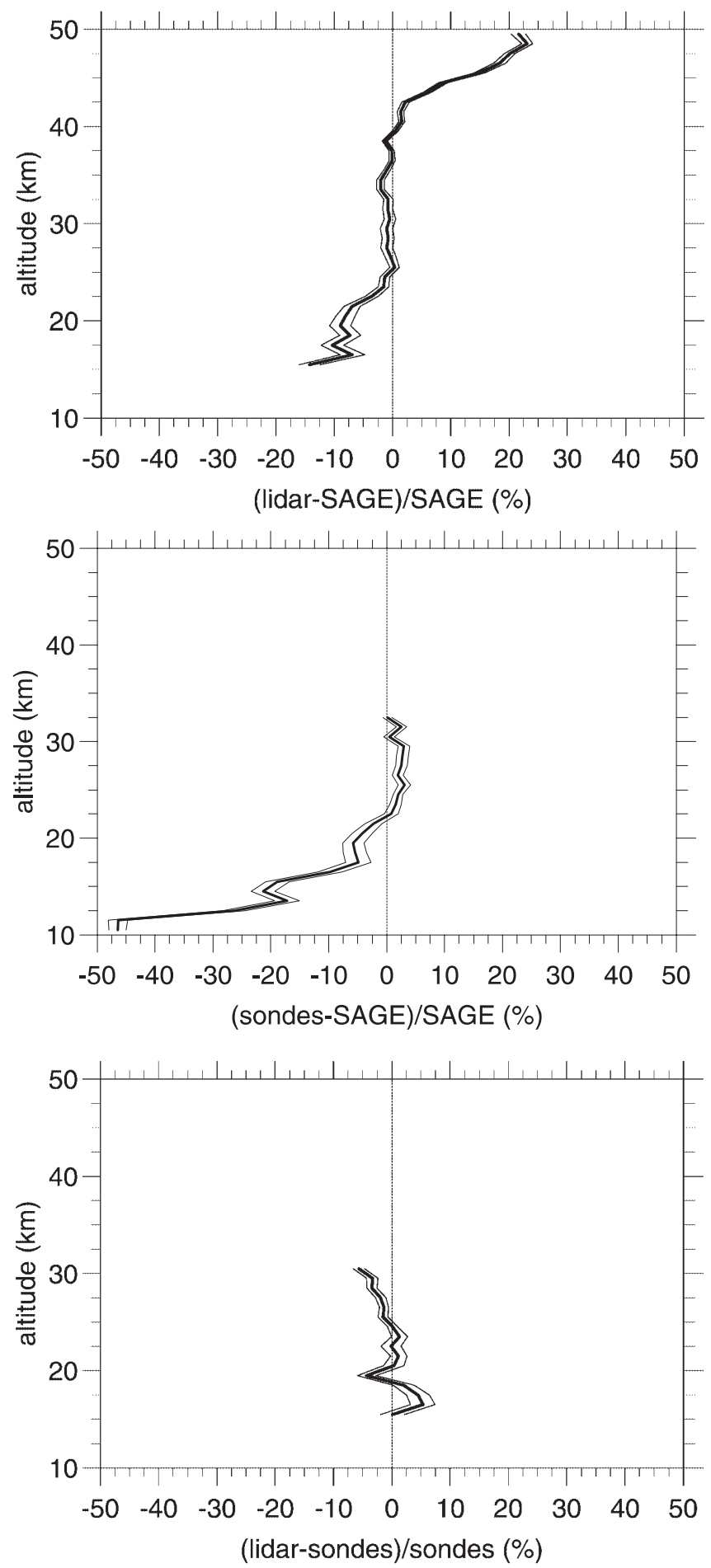

Fig. 5. Same as Fig. 4, with data sets being restricted to only measurements in temporal coincidence

vary from $-8.8 \%$ at $15.5 \mathrm{~km}$ to $-1.2 \%$ at $20.5 \mathrm{~km}$ (Fig. 4). Between 21 and $28 \mathrm{~km}$, the relative differences of the profiles can partly be explained by the different sampling rate of the instruments, as shown by the smaller values of the relative difference calculated with only measurements in temporal coincidence (between $-3.4 \%$ at $28 \mathrm{~km}$ and $0.1 \%$ at $24 \mathrm{~km}$ ) (Fig. 5). Concerning the other altitudes, one should keep in mind that there is a low number of lidar measurements available in the altitude range 15-20 km before 1994 and a low number of ozonesonde measurements available in the altitude range $25-30 \mathrm{~km}$ for the whole period.

The vertical profiles of the standard deviation of the mean profiles (Fig. 3) show similar values for lidar, SAGE II and ozonesonde measurements above $25 \mathrm{~km}$. The standard deviation determined from Umkehr measurements is lower at all altitudes. This could be related to the lower vertical resolution of these measurements, which thus integrate part of the variability. Similarly, the standard deviation derived from lidar measurements is lower below $20 \mathrm{~km}$ as compared to SAGE II and ozonesonde measurements, reflecting again the lower resolution of lidar measurements in this altitude range (see Sect. 2.1).

\section{Long-term evolution of ozone vertical distribution at OHP}

The assessment of trends will be restricted to altitude ranges where the measurements are valid and available without temporal gaps. Therefore, based on the results of Sects. 2.1, 2.2 and 3, the trend calculation will be limited to specific time periods and altitude ranges for each instrument. This selection will also ensure that the number of ozone measurements available will be similar for the various instruments. As such, ozonesonde measurements will be used only between 10 and $25 \mathrm{~km}$, lidar data only between 25 and $40 \mathrm{~km}$ and SAGE II data only between 22 and $50 \mathrm{~km}$. The Umkehr measurements will be used only in layers 4 to 8 which are the only ones providing independent information (WMO, 1988).

All time series used in this study are restricted to the end of 1995 (Table 1). The length of the data sets is thus short compared to the time scales of some of the processes that drive the variability of the ozone layer, such as the occurrence of volcanic eruptions or the 11year solar cycle. Nevertheless, the complementarity of the different experiments providing measurements in the same place over the same period of time could lead to preliminary conclusions on the long-term evolution of the ozone vertical distribution at OHP.

\subsection{Method of analysis}

The method of analysis is based on a multiparameter least-squared fit of the monthly means to extract the trend from other variations of the ozone vertical distribution (Press et al., 1989). As the ozone data sets used for this study are not exactly of the same time length, it is necessary to remove the main components of the interannual variability for each of the data sets, in order to compare and analyse the trends inferred from each of them. The regression model has been developed and adapted from the so-called AMOUNTS temperature trend model of Hauchecorne and Keckhut (Hauchecorne et al., 1991; Keckhut et al., 1995, 1999). The statistical parameters associated with this fitting method 
are described in Appendix A. The components of the ozone variability taken into account include the seasonal variations of ozone concentrations, and the response to the quasi-biennial oscillation (QBO), to the 11-year solar cycle, and to the stratospheric aerosol forcing. The seasonal cycles are parameterised using a constant term and a sine and cosine annual and semi-annual functions. The ozone concentration at time $t$ and altitude $z$ is represented by:

$$
\begin{aligned}
\mathrm{O}_{3}(t, z)= & \mathrm{O}_{3}^{\prime}(t, z)+a_{0}(z) \\
& +a_{A_{1}}(z) \times c_{A_{1}}(t, z)+a_{A_{2}}(z) \times c_{A_{2}}(t, z) \\
& +a_{B_{1}}(z) \times c_{B_{1}}(t, z)+a_{B_{2}}(z) \times c_{B_{2}}(t, z) \\
& +a_{\mathrm{QBO}}(z) \times c_{\mathrm{QBO}}(t, z)+a_{\mathrm{sol}}(z) \times c_{\mathrm{sol}}(t, z) \\
& +a_{\text {aero }}(z) \times c_{\text {aero }}(t, z)+a_{T}(z) \times c_{T}(t, z)
\end{aligned}
$$

where: $a_{A_{1}}(z), \ldots, a_{T}(z)$ are the coefficients computed by the model for the different forcings; $c_{A_{1}}(t), \ldots, c_{T}(t)$ describe the temporal evolution of the forcings; $\mathrm{O}_{3}^{\prime}(t, z)$ is the deviation term from the best fit.

The quasi-biennial oscillation (QBO) influences the circulation at mid-latitudes and consequently the ozone distribution in those regions (Randel and $\mathrm{Wu}, 1996$; Sitnov, 1996). The confidence interval of the further derived trend component decreases when the QBO signal is removed from the time series, according to previous results (Keating et al., 1994a). Thus, to infer ozone trends as accurately as possible, the QBO signal is removed in all of the following studies. However, the amplitude of this ozone response to the QBO has been shown to be rather low (Logan, 1994), and our analyses also show that this contribution to the long-term evolution of the ozone at OHP is generally not significant. The QBO proxy used in this study corresponds to the wind velocities at $45 \mathrm{hPa}$ measured by radiosoundings at Singapore $\left(1.22^{\circ} \mathrm{N}, 103.55^{\circ} \mathrm{E}\right)$ :

$c_{\mathrm{QBO}}(t)=w_{45 \mathrm{hPa}}(t)$

and provided by B. Naujokat (Meteorologisches Institut, Frei Universität Berlin, Germany).

The solar induced variability comes from variations of the solar activity (Hood et al., 1993; Keating et al., 1994b; Hood, 1997) especially at wavelengths lower than $200 \mathrm{~nm}$, for which the solar flux plays a dominant role in the dissociation process of molecular oxygen. The solar index used in this study is the He I index, which corresponds to the variation in the linewidth of the He I absorption transition at $1083 \mathrm{~nm}$ :

$c_{\mathrm{sol}}(t)=I_{\mathrm{He}}(t)$

Data are available from observations at the Kitt Peak Observatory (Arizona, United States) over the time period of ozone measurements at OHP and are provided by the Solar Index Data Base from the Observatoire de Meudon (France).

The largely enhanced aerosol loading which occurred in the stratosphere following the eruption of Mount Pinatubo in June 1991 increased the surface areas available for heterogeneous chemical reactions leading to increased destruction of ozone below $25 \mathrm{~km}$ (Tie et al., 1994; Solomon et al., 1996, 1998). This effect has been estimated to correspond, at northern mid-latitudes, to a decline ranging between 3 and $12 \%$ for the total ozone, (WMO, 1991) and about $15 \%$ in the $8-24 \mathrm{~km}$ altitude range (Angell, 1998).

To take into account the chemical depletion in ozone concentration in the lower stratosphere, and following the approach of Portmann et al. (1996), a proxy index is considered which corresponds to the product:

$c_{\text {aero }}(t, z)=S(t, z) \times \Delta \mathrm{Cl}(t)$

where $S(t, z)$ is the aerosol surface area density as calculated by Jackman et al. (1996) and Thomason and Poole (1997) from the SAGE measurements for the 40$50^{\circ} \mathrm{N}$ latitude band; and $\Delta \mathrm{Cl}(t)$ is the variation of the stratospheric chlorine loading which is considered as having increased linearly by $36 \%$ between October 1984 and December 1995 (WMO, 1994; Solomon et al., 1996).

As pointed out by Solomon et al. (1996), it is worth noting that a possible confusion can be made between the aerosol loading and the 11-year solar cycle signals on ozone changes. Both peak in 1991, with recovery (volcanic aerosols) and minimum (solar activity) occurring simultaneously in 1995 which corresponds to the end of the time period of this study. However, these two processes do not affect the stratospheric ozone concentration in the same altitude ranges. Therefore, the study of the long-term evolution of the ozone vertical distribution as performed here could allow to differentiate between the solar cycle and aerosol loading induced ozone changes. The model also includes a trend function which is linear as a function of time to account for the long-term ozone depletion.

The model will be referred hereafter as the AMOUNTS $\mathrm{O}_{3}$ statistical model. A validation exercise has been completed by comparing the trends estimated by this statistical model on a reference time series, namely the TOMS total ozone measurements for the 40 $45^{\circ} \mathrm{N}$ latitude band between $01 / 1979$ and $05 / 1991$, with those calculated using validated statistical models (WMO, 1994). For the seasonal trends and the yearround values, there is a very good agreement between the values retrieved using the AMOUNTS $\mathrm{O}_{3}$ model with those published in WMO (1994), with a maximum difference of $0.4 \% /$ decade.

\subsection{Seasonal variations of the ozone vertical distribution}

The variation of ozone at mid-latitudes is controlled by both chemical and physical processes, leading to annual and semi-annual altitude dependent cycles (Brasseur and Solomon, 1986; WMO, 1994; Guirlet, 1997). The main objective of this section is to assess the ability of the various instruments to monitor the atmospheric interannual variability, before investigating the influence of other processes on the long-term evolution of ozone. The definition of the amplitude and phase of the annual and semi-annual variations is given in Appendix A.

Concerning the amplitude of the seasonal variation for both annual and semi-annual cycles, there is a good 
agreement between the results obtained from the different instruments (Fig. 6). For all of them, the amplitude of the annual variations is maximum at $20 \mathrm{~km}$ (between $8.1 \times$ $10^{11} \mathrm{~mol} \cdot \mathrm{cm}^{-3}$ for the lidar and $9.9 \times 10^{11} \mathrm{~mol} \cdot \mathrm{cm}^{-3}$ for SAGE II; $8.1 \mathrm{DU}$ for Umkehr) and minimum at $25 \mathrm{~km}$ (between $4.0 \times 10^{10} \mathrm{~mol} \cdot \mathrm{cm}^{-3}$ for the ozonesondes and $1.5 \times 10^{11} \mathrm{~mol} \cdot \mathrm{cm}^{-3}$ for the lidar; 2.1 DU for Umkehr). A secondary maximum is derived at $30 \mathrm{~km}$ from SAGE II $\left(4.5 \times 10^{11} \mathrm{~mol} \cdot \mathrm{cm}^{-3}\right)$, lidar $(5.8 \times$ $\left.10^{11} \mathrm{~mol} \cdot \mathrm{cm}^{-3}\right)$ and Umkehr (5.0 DU) measurements. At altitudes below $20 \mathrm{~km}$, the amplitude of the annual variation as derived from lidar, SAGE II and ozonesondes decreases to similar values at $15 \mathrm{~km}$ altitude $\left(5.2 \times 10^{11} \mathrm{~mol} \cdot \mathrm{cm}^{-3}, \quad 7.2 \times 10^{11} \mathrm{~mol} \cdot \mathrm{cm}^{-3}, \quad 6.4 \times\right.$ $10^{11} \mathrm{~mol} \cdot \mathrm{cm}^{-3}$ respectively). The maximum observed at altitudes below $15 \mathrm{~km}$ from the ozonesonde record could be related to the higher variability of the ozone vertical distribution at the tropopause level due to stratosphere-troposphere exchange processes and the variation of tropopause altitude (see also the phase of this variation, Fig. 7). For all measurements, the amplitude of the semi-annual variation is much lower than the annual cycle and decreases with altitude above $15-18 \mathrm{~km}$. All four instruments show a very low level of variability in the ozone profile at $25 \mathrm{~km}$ which corresponds to the upper part of the ozone maximum.

As for their amplitudes, the values of the phase of the seasonal variations show a good coherence between the different data sets (Fig. 7). For the four data sets, the amplitude of the annual variation is maximum between February and April at the altitude levels lower than $25 \mathrm{~km}$, and between June and August at the altitude levels higher than $25 \mathrm{~km}$. One should note that at altitude levels higher than $30 \mathrm{~km}$, the value of the phase of the annual variation of ozone concentration is similar to the one of temperature as observed from lidar measurements at OHP (Hauchecorne et al., 1991). The amplitude of the semi-annual variation is maximum in spring and in autumn for the altitude levels lower than $20 \mathrm{~km}$, and in winter and in summer for the altitude levels higher than $25 \mathrm{~km}$.

These main characteristics of the ozone seasonal variations are in agreement with $2 \mathrm{D}$-model calculations (Brasseur et al., 1990) of ozone variations at northern hemisphere mid-latitudes (Guirlet, 1997). As such, the very obvious change in the amplitude and phase observed at the $25 \mathrm{~km}$ altitude level from the four measurement techniques is consistent with the change in the processes that control ozone vertical distribution. These include dynamical control for altitudes lower than the altitude level of the maximum ozone concentration, and chemical control above $30 \mathrm{~km}$.

In conclusion, there is a rather good agreement between the results of the various experimental data sets showing their coherence in retrieving the seasonal variations throughout the whole period of time considered in this study. This coherence will allow us to subtract the seasonal variations for all experiments with a high degree of confidence, before calculating the influence of other processes in the next sections.

\subsection{Quantification of the long-term evolution of stratospheric ozone at $\mathrm{OHP}$}

In this section, a first estimate of the long-term evolution is given for both total ozone and ozone vertical
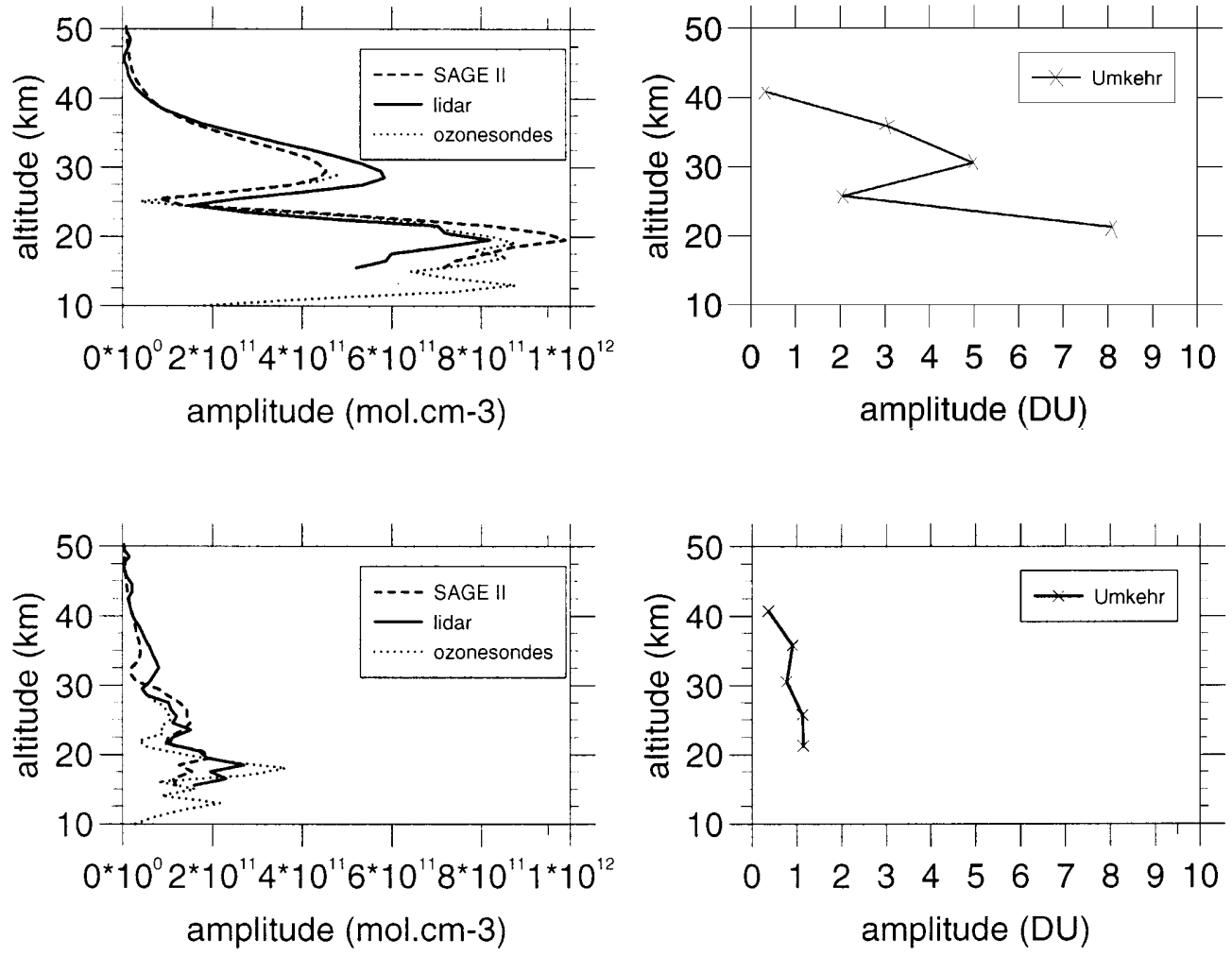

Fig. 6. Altitude dependence of the amplitudes of the annual (top row) and semi-annual (bottom row) ozone variations as derived from SAGE II, lidar, ozonosonde (left column) and Umkehr measurements (right column). For Umkehr measurements, the altitude of reference is the centre altitude of the Umkehr layer 

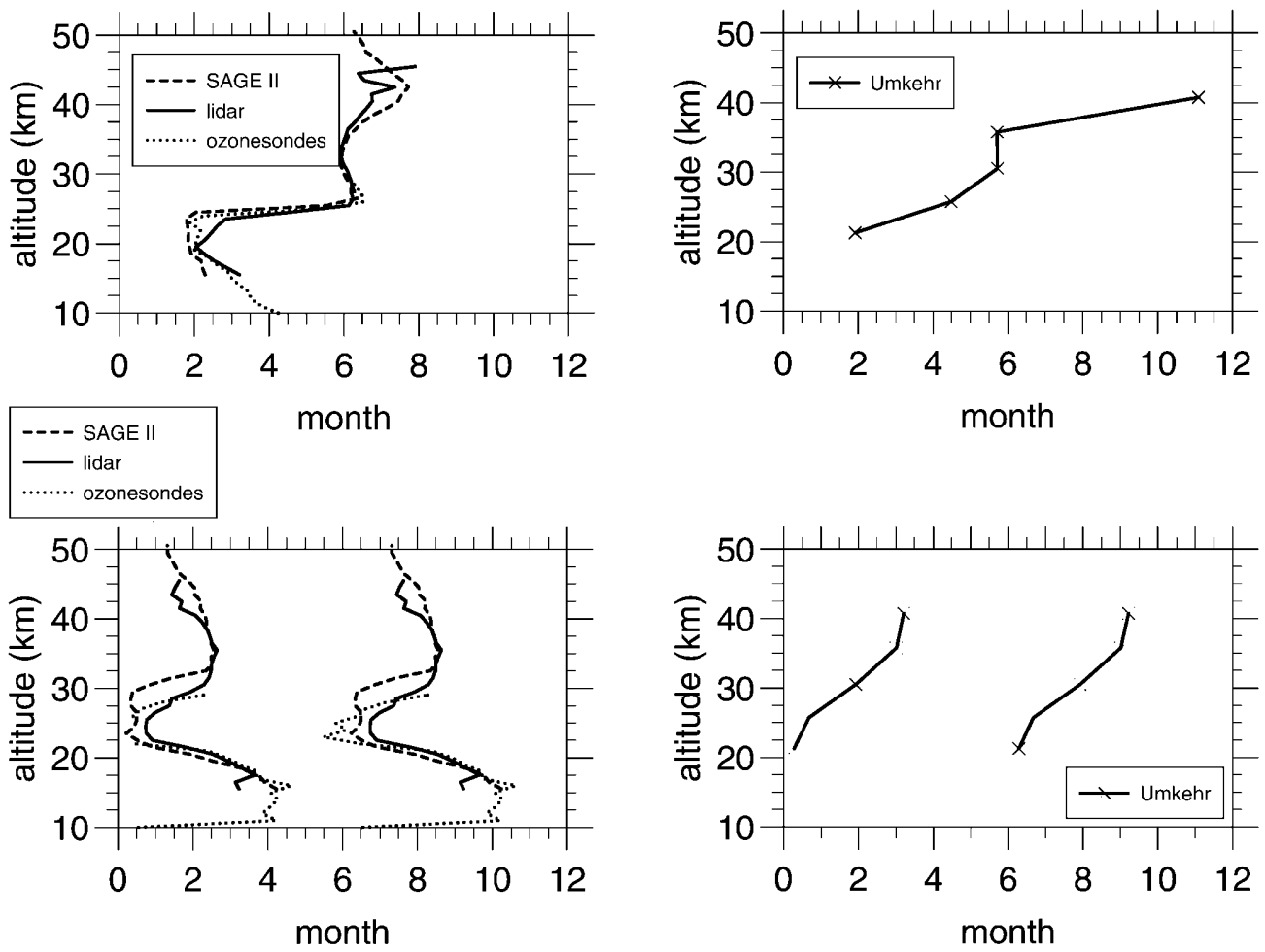

Fig. 7. Altitude dependence of the phases of the annual (top row) and semi-annual (bottom row) variations as derived from SAGE II, lidar, ozonesonde (left column) and Umkehr measurements (right column) at OHP. The phase of the semi-annual variation is given with a 6 months period. For Umkehr measurements, the altitude of reference is the centre altitude of the Umkehr layer

distribution. This calculation takes into account the seasonal variations, the $\mathrm{QBO}$ and the 11-year solar cycle. The effect of the aerosols will be discussed afterwards with reference to ozonesonde measurements. All uncertainties reported hereafter correspond to $1 \sigma$ standard deviation.

4.3.1 Trends in total ozone. The trends in total ozone are calculated using the Dobson measurements at OHP for both seasonal values (with winter extending from the 1st of December to the 1st of March) and year-round values.

The annual trend at OHP calculated using the AMOUNTS $\mathrm{O}_{3}$ model is $-5.4 \% \pm 1.7 \%$ per decade over the period 1983-1995 (Fig. 8). It has to be compared with the trend value of $-4.4 \% \pm 1.15 \%$ per decade reported in (WMO, 1998) for the same station over the period 1983-1997 which includes the recovery period after the Mount Pinatubo eruption. According to the WMO (1998), the difference in the northern hemisphere $\left(35^{\circ} \mathrm{N}, 60^{\circ} \mathrm{N}\right)$ between trends calculated until the end of 1995 and end of 1997 is of the order of $1 \%$, giving thus confidence in the total ozone trend values derived at OHP.

As for most of the stations in the northern hemisphere mid-latitudes, the trends are more negative in winter and spring (Fig. 8). Indeed no significant trends are found in summer and autumn at the $1 \sigma$ confidence level (WMO, 1998). The seasonal trend values obtained at OHP over the periods 1983-1995 and 1983-1997 are shown on Fig. 8 and compared to the trends derived from TOMS measurements from 1979 and 1997 and averaged over the latitude band $40-45^{\circ} \mathrm{N}$ (WMO, 1998). The seasonal effect is much more marked for the OHP

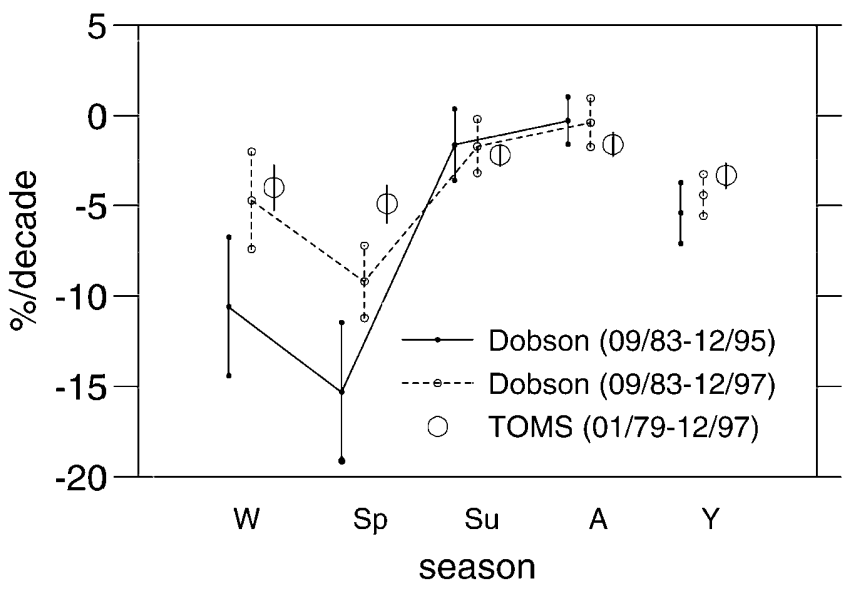

Fig. 8. Ozone trends derived from Dobson measurements at OHP between September 1983 and December 1995 and between September 1983 and December 1997 (WMO, 1998); ozone trends derived from TOMS measurements between January 1979 and December 1997 (WMO, 1998). Trends are given in \% per decade with a $1 \sigma$ uncertainty limit for the four seasons winter, spring, summer, autumn $(\mathrm{W}, \mathrm{Sp}, \mathrm{Su}, \mathrm{A})$ and for the whole year $(Y)$. The seasonal variations, the QBO and the 11-year solar cycle have been removed

data. Similarly increased values for the springtime trends are also observed for the period between 1979 and 1997 in nearby European stations such as Hohenpeissenberg $[-7.2 \% \pm 1.55 \%$ per decade (WMO, 1998)] and Vigna di Valle $[-7.6 \% \pm 1.8 \%$ per decade (WMO, 1998)]. Though the starting date of the series strongly influences the trend value, the difference between the trend values could also partly be due to a longitude dependent effect already shown by several authors (Stolarski et al., 1992; Hood and Zaff, 1995; Chandra 
et al., 1996; Bojkov et al., 1998). Further analysis would certainly be required to confirm this effect.

\subsubsection{Trends in stratospheric ozone vertical distribu-} tion. The reduction in total ozone is associated with a negative trend of the ozone profile in the stratosphere, as revealed by the analyses of the ozone profile measurements (Fig. 9). The SAGE II derived altitude dependent trend decreases rather regularly as a function of altitude above $25 \mathrm{~km}$ up to $40 \mathrm{~km}$ where it reaches $-8.5 \% \pm$ $1.9 \% /$ decade over the period 1984-1995. In the same altitude range and taking into account the coarse vertical resolution of the Umkehr measurements, the Umkehr derived trends in layers 6 to 8 are in rather good agreement with the SAGE II derived values. No significant trend is observed from Umkehr measurements in layers 4 and 5.

Although the trend values derived from lidar measurements are more negative than the SAGE II values between 28 and $34 \mathrm{~km}$, the differences are not significant at the $1 \sigma$ confidence level. Indeed, there is a rather good agreement between the altitude dependent trends derived from these two instruments at lower (between 25 and $28 \mathrm{~km}$ ) and upper altitudes (up to $38 \mathrm{~km}$ ). At the altitudes higher than $38 \mathrm{~km}$, the differences between the trend values inferred from lidar and from SAGE II measurements may have the same origin as the bias between lidar and SAGE II measurements (Fig. 5; Sect. 3), confirming that trend estimates inferred from lidar measurements at those altitudes are not significant.

This picture of altitude dependent trends as observed at OHP is roughly consistent with what could be expected based on previous studies using longer term records in the northern hemisphere mid-latitudes (SPARC-IOC, 1998). The upper altitude trends (35$40 \mathrm{~km}$ ) are linked to ozone destruction by gas phase chlorine catalytical cycles and the observed values at OHP from SAGE II and Umkehr measurements are in

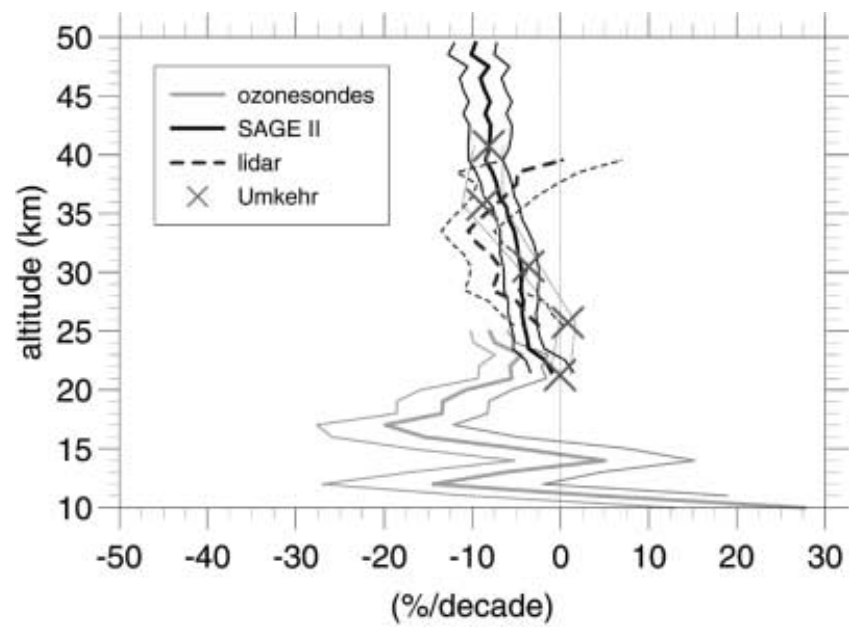

Fig. 9. Ozone trends as a function of altitude derived from SAGE II, lidar, ozonosondes, and Umkehr measurements at OHP. Trends are given in $\%$ per decade with $1 \sigma$ uncertainty limits after removal of the seasonal variations, the QBO and the 11-year solar cycle agreement with model calculations (WMO, 1994). In the intermediate altitude levels between 25 and $35 \mathrm{~km}$, significant negative trends are also observed from other data records (SPARC-IOC, 1998), but the absolute values inferred from measurements at OHP seem rather large and do not agree with present model calculations. This might be related to an insufficient length of the data record, especially for the lidar measurements.

In the lower stratosphere, where no results other than those derived from ozonesonde measurements are available, the trends are largely negative (Fig. 9). The maximum value of the absolute amplitude is obtained at the $17 \mathrm{~km}$ altitude level $(-19.9 \% \pm 7.8 \%$ /decade over the period 1984-1995). Large negative values are computed up to $25 \mathrm{~km}$ altitude from the ozonesonde measurements. Those values are larger than those calculated from simulation models which include heterogeneous processes on sulfate aerosols and transport from higher latitudes where larger ozone losses are observed (WMO, 1998). At this stage of the analysis, we can not dismiss the facts that: (1) the changes in the operational procedure may have altered the long-term continuity of the measurements; (2) the large decrease observed after the Mount Pinatubo eruption in this altitude range might have also impacted on the trend values calculated until only 1995. Nevertheless, it is worth noting that the integration of the vertical profile of ozone trends derived from ozonesonde measurements between 10 and $25 \mathrm{~km}$ and of the vertical profile of ozone trends derived from SAGE II measurements between 25 and $50 \mathrm{~km}$, leads to a decrease of $-6.4 \%$ /decade, which is in reasonable agreement with the value derived from year-round Dobson measurements $(-5.4 \% /$ decade $)$ over the same period. As the upper altitude trends inferred from the SAGE II measurements are in agreement with model calculations, there might be a slight overestimation of the amplitude of trends inferred from ozonesondes as compared to the trends inferred from Dobson measurements, taking into account the fact that, as previously discussed, the ozonesondes may not provide ideally reliable measurements in the lower stratosphere. Nevertheless, because of the agreement between trends in the upper stratosphere and the model calculations, the large negative values inferred from both ozonesonde measurements in the lower stratosphere and from Dobson measurements in winter and spring are likely to result from a time evolution of the ozone profile rather than from an instrumental effect only.

4.3.3 Influence of the 11-year solar cycle and of the volcanic aerosol loading. Considering the altitude dependence of the 11-year solar cycle contribution, the values as derived from the SAGE II measurements show a positive effect (from solar minimum to solar maximum) between 35 and $45 \mathrm{~km}$, reaching a maximum of $4.4 \%$ per solar cycle at $41 \mathrm{~km}$ (Fig. 10). This is in agreement with previously reported results, as well as low negative values observed around $30 \mathrm{~km}$ (Miller et al., 1996). 


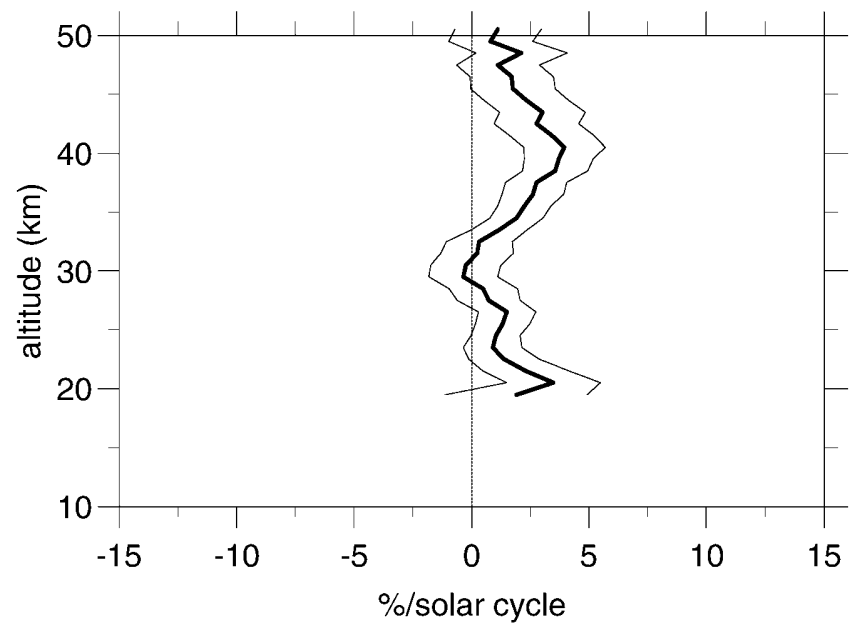

Fig. 10. Solar contribution with $1 \sigma$ standard deviation limits as a function of altitude as derived from SAGE II measurements at OHP. Values are given in \% per solar cycle

The trend estimates presented up to this point were calculated without taking into account the effects of stratospheric aerosols. Including those could be made by using the methodology described in Sect. 4.1. The vertical profiles of trends derived from ozonesonde measurements with and without an aerosol term are presented on Fig. 11. This comparison shows that taking into account the volcanic aerosol effect leads to a reduction of the amplitude of the trend, with a maximum effect of $4 \%$ /decade between 15 and $18 \mathrm{~km}$.

\section{Concluding remarks}

The present comparative studies have shown that the lidar is the only ground-based instrument that can provide reliable measurements of the ozone vertical profile in the whole altitude range between 15 and $40 \mathrm{~km}$. However, this is achieved only with up-to-date systems which include all technological improvements developed over the last decade. These include the reduction in signal induced noise at higher altitudes by the use of a mechanical chopper, the adaptation to the high signal dynamics by the use of several optical receiving channels, and the due account of aerosol interferences in the lower stratosphere by using the DIAL Raman scattering technique as recommended by the NDSC protocol. These improvements have been made gradually between 1986 and 1994 at OHP, which explains why the present data record cannot be considered with a high level of confidence throughout the whole stratosphere. Indeed, the statistical analysis of the long-term lidar data set demonstrates that reliable trends can only be derived in a restricted altitude range from 25 to $38 \mathrm{~km}$. Based on a simple analysis which takes into account the observed variability in the ozone field and present instrumental uncertainties (see Appendix B), one can calculate the earliest dates at which reliable trends will be derived at OHP as a function of altitude (Table 2). The results show that reliable trend estimates could be made within the next few years and thus before the turn over of stratospheric chlorine loading which is due to occur in the beginning of this century (WMO, 1998).

With those comparative studies, we also demonstrated the requirement for continuous long-term operation, over at least two or three decades, with appropriate continuous instrument evaluation at OHP and any other

Table 2. Requirement on the length of a given time series for detection of a significant trend at the $95 \%$ confidence level from lidar measurements at OHP. $n_{0}$ is the timelength in months for each altitude level. The last column gives the expected year of achievement considering the starting date of the measurement series at OHP (in brackets)

\begin{tabular}{lclllrl}
\hline Altitude & $\sigma_{\mathrm{r}}(\%)$ & $t(\mathrm{z})(\%)$ & $\Delta t$ & $\varphi$ & \multicolumn{1}{l}{$n_{0}$} & Year \\
\hline 15 & 16.5 & -7.0 & $1 / 12$ & 0.20 & 42 & $1998(1994)$ \\
20 & 11.3 & -5.0 & $1 / 12$ & 0.11 & 63 & $1999(1994)$ \\
25 & 6.3 & -3.0 & $1 / 12$ & 0.00 & 156 & $1999(1986)$ \\
30 & 7.0 & -2.0 & $1 / 12$ & 0.07 & 92 & $1995(1986)$ \\
35 & 7.6 & -5.0 & $1 / 12$ & 0.09 & 92 & $1995(1986)$ \\
40 & 14.1 & -7.0 & $1 / 12$ & 0.12 & 140 & $1998(1986)$ \\
\hline
\end{tabular}

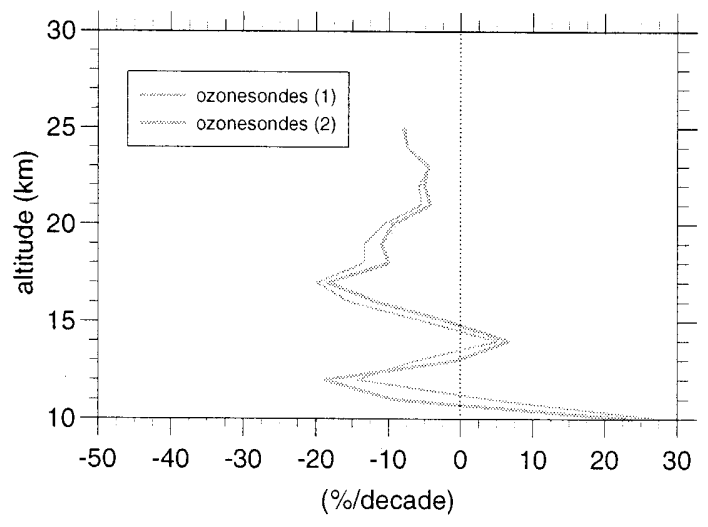

Fig. 11. Ozone trends in $\% /$ decade as a function of altitude as derived from ozonosonde measurements at OHP (left panel); curve (1) is the same as in Fig. 9, i.e. without considering the aerosol effect;

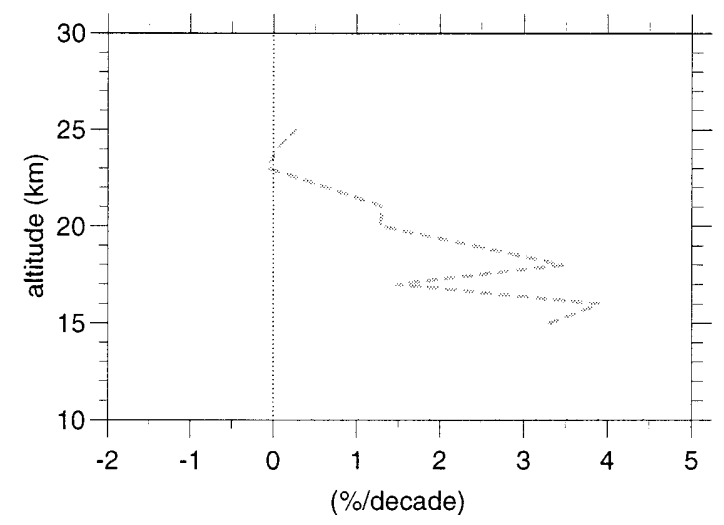

curve (2) corresponds to estimated trends when removing the effect of aerosol forcing. Difference between curve (2) and curve (1) as a function of altitude (right panel) 
NDSC station. This was part of the objectives of the Network for Detection of Stratospheric Change implemented when mid-latitude trends were first observed 10 years ago, with the aim to produce high quality longterm data sets for ozone assessment. According to the present study, this must be based on the complementarity and the overlap of the data sets, as they appear to be needed highly for a reliable monitoring of long-term evolution of ozone.

Acknowledgements. We would like to thank M. Newchurch (University of Alabama in Huntsville) for providing the Umkehr data and B. Naujokat (Institut fuer Meteorologie, Frei Universität Berlin) for providing the wind measurements at Singapore. The SAGE II ozone data were obtained from the NASA Langley Research Center EOSDIS Distributed Active Archive Center. NSO/Kitt Peak data used here are produced cooperatively by NSF/NOAO, NASA/GSFC and NOAA/SEL. The data of stratospheric aerosol surface area density from Thomason and Poole (1997) are available on Internet. The Dobson spectrometer at the OHP is operated under the responsibility of A. Barbe and M.F. Mérienne (Groupe de Spectrométrie Moléculaire de Reims) and of S. Oltmans (NOAA). The ozonesonde measurements are under the responsability of G. Ancellet and C. Vialle (Service d'Aéronomie IPSL). The authors also wish to thank the technical staff at OHP: P. Da Conceicao, G. Gabelou, P. Gildwarg, F. Gomez, G. Kaczmarek, J.P. Schneider, F. Syda, and G. Velghe. The OHP NDSC station routine operation is supported by CNRS, INSU, CNES, ADEME, the Ministère de l'Enseignement Supérieur et de la Recherche and the Ministère de l'Environnement. This work has also been supported by the European Commission Environment and Climate Programme (ESMOS and CASSIS projects), the Programme National de Chimie Atmosphérique (CNRS), and the UK Department of the Environment, Transport and Regions.

Topical Editor D. Murtagh thanks M. de Maziere and another referee for their help in evaluating this paper.

\section{Appendix A: statistical method}

The ozone concentration at time $t_{j}$ and altitude $z_{i}$ is represented by:

$O_{3}\left(t_{j}, z_{i}\right)=\sum_{k=1}^{p} a\left(z_{i}, k\right) \times c\left(t_{j}, k\right)+O_{3}^{\prime}\left(t_{j}, z_{i}\right)$

where:

$c\left(t_{j}, k\right)$ describes the temporal evolution of the forcing $k$;

$a\left(z_{i}, k\right)$ is the coefficient computed by the model for the forcing $k$;

$O_{3}^{\prime}\left(t_{j}, z_{i}\right)$ is the deviation term from the best fit.

The computation is made in order to minimize the quantity:

$\chi^{2}\left(z_{i}\right)=\left[\sum_{t_{j}}\left(O_{3}\left(t_{j}, z_{i}\right)-\sum_{k} a\left(z_{i}, k\right) \times c\left(t_{j}, z_{i}\right)\right]^{2}\right.$

The variance of the residual term is defined as:

$\sigma_{r}^{2}(z)=\frac{\chi^{2}(z)}{n-p}$

where $n$ is the number of profiles, and $p$ is the number of forcings. In the theoretical case of no correlated measurements, the confidence interval for the trend is determined as:

$\sigma_{k}^{2}(z)=\frac{1}{\sum_{i=1}^{n}\left[\left(t_{i}-t\right)^{2}\right]} \times \frac{\chi^{2}(z)}{n-p}$

In the general case, when two successive measurements are not fully independent, the confidence interval is corrected using a correlation term $\varphi(z)$ defined as: $\sigma_{k}^{2}(z)=\frac{1}{\sum_{i=1}^{n}\left[\left(t_{i}-t\right)^{2}\right]} \times \frac{\chi^{2}(z)}{n-p} \times \frac{(1+\varphi(z))}{(1-\varphi(z))}$

where the correlation term $\varphi(z)$ is given by:

$\varphi(z)=\frac{\sum_{j=1}^{n-1} O_{3}^{\prime}\left(z_{i}, t_{j}\right) \times O_{3}^{\prime}\left(z_{i}, t_{j+1}\right)}{\sum_{j=1}^{n-1} \frac{O_{3}^{\prime}\left(z_{i}, t_{j}\right)^{2}+O_{3}^{\prime}\left(z_{i}, t_{j+1}\right)^{2}}{2}}$

with the variance defined as:

$\sigma_{\Phi}^{2}(z)=\frac{1-\varphi^{2}(z)}{\sqrt{n-1}}$

The autocorrelation function is assumed to decrease exponentially with a time constant $\tau$ :

$\Phi(t, t+\triangle t)=\exp \frac{-\triangle t}{\tau}$

so that a characteristic correlative time between two successive measurements is determined as:

$\tau=-\frac{\triangle t}{\ln \Phi_{\mathrm{th}}}$

The amplitude of the annual and semi-annual variations is defined by:

$A\left(z_{i}\right)=\sqrt{a\left(z_{i}, k_{1}\right)^{2}+a\left(z_{i}, k_{2}\right)^{2}}$

and the phase of the annual and semi-annual variations is defined by:

$\varphi\left(z_{i}\right)=(12 / 2 \pi) * \operatorname{Arctan}\left(a\left(z_{i}, k_{1}\right) / a\left(z_{i}, k_{2}\right)\right)$

where $a\left(z_{i}, k_{1}\right)$ and $a\left(z_{i}, k_{2}\right)$ are the coefficients of the annual or the semi-annual variations.

\section{Appendix B: requirement on the length of a time series}

The number of monthly means required to detect a trend from the lidar measurements with a $95 \%$ confidence level has been estimated for various altitude levels: $15,20,25,30,35$ and $40 \mathrm{~km}$. This calculation is based on the formula given by Frederick (Frederick, 1984; Keckhut et al., 1995) which expresses the number of monthly means $n_{0}(z)$ as:

$n_{0}(z)=3.58 \times\left[\left(\frac{\sigma_{r}(z)}{t(z) \times \triangle t}\right)^{2} \frac{1-\varphi(z)^{2}}{(1-\varphi(z))^{2}}\right]^{(1 / 3)}$

where $t(z)$ is the trend value at altitude $z$, estimated from values given in the 1994 Science Assessment (WMO, 1994). This estimation is also based on the hypothesis of a regular sampling rate.

The results obtained (Table 2) underline that significant trend will now be detected within only a few years (1998-1999), for the $15,20,25$ and $40 \mathrm{~km}$ altitude levels, taking into account that most of the measurements below $25 \mathrm{~km}$ are available only after 1993. In the altitude range from 30 to $35 \mathrm{~km}$, trend detection can be made with the presently available record.

\section{References}

Ancellet, G., and M. Beekmann, Evidence for changes in the ozone concentrations in the free troposphere over Southern France from 1976 to 1995, Atmos. Environ., 31, 2835-2851, 1997.

Angell, J. K., Impact of El Chichon and Pinatubo on ozonesonde profiles in north extratropics, Geophys. Res. Lett., 25, 44854488, 1998.

Attmannspacher, W., J. de La Noé, D. de Muer, J. Lenoble, G. Mégie, J. Pelon, P. Pruvost, and R. Reiter, European validation of SAGE II profiles, J. Geophys. Res., 94, 8461-8466, 1989.

Beekmann, M., G. Ancellet, G. Mégie, H. G. Smit, and D. Kley, Intercomparison campaign of vertical ozone profiles including 
electrochemical sondes of E.C.C. and Brewer-Mast and a ground-based UV-differential absorption lidar, J. Atmos. Chem., 19, 259-288, 1994.

Bojkov, R. D., and V. E. Fioletov, Estimating the global ozone characteristics during the last 30 years, J. Geophys. Res., 100, 16 537-16 551, 1995.

Bojkov, R. D., D. S. Balis, and C. S. Zerefos, Characteristics of the ozone decline in the Northern and middle latitudes during the winter-spring, Meteorol. Atmos. Phys., in press, 1998.

Brasseur, G., and S. Solomon, Aeronomy of the middle atmosphere, D. Reidel Publishing Company, Dordrecht, 1986.

Brasseur, G., M. H. Hitchman, S. Walters, M. Dymek, E. Falise, and M. Pirre, An interactive chemical dynamical radiative twodimensional model of the middle atmosphere, J. Geophys. Res., 95, 5639-5655, 1990.

Chandra, S., C. Varotsos, and L. E. Flynn, The mid-latitude total ozone trends in the northern hemisphere, Geophys. Res. Lett., 23, 555-558, 1996.

Chu, W., and P. Mc Cormick, Inversion of stratospheric aerosols and gaseous constituents from spacecraft solar extinction data in the 0.38-1.0 $\mu \mathrm{m}$ wavelength region, Appl. Opt., 18, 1404-1414, 1979.

Chu, W. P., P. Mc Cormick, J. Lenoble, C. Brogniez, and P. Pruvost, SAGE II inversion algorithm, J. Geophys. Res., 94, 8339-8351, 1989.

Cunnold, D. M., W. P. Chu, R. A. Barnes, M. P. Cormick, and R. E. Veiga, Validation of SAGE II ozone measurements, J. Geophys. Res., 94, 8447-8460, 1989.

Cunnold, D. M., H. Wang, W. P. Chu, and L. Froidevaux, Comparisons between Stratospheric Aerosol and Gas Experiment II and microwave limb sounder ozone measurements and a liasing of SAGE II ozone trends in the lower stratosphere, J. Geophys. Res., 101, 10 061-10 075, 1996.

Dobson, G. M. B., A photoelectric spectrophotometer for measuring the amount of atmospheric ozone, Proc. Phys. Soc. London, 43 324-43 339, 1931.

Dobson, G. M. B., Observers handbook for the ozone spectrophotometer, Ann. Int. Geophys. Year, 5, 46-89, 1957.

Frederick, J. E., Measurement requirements for the detection of ozone trends, in Ozone correlative measurements workshop, NASA Conf. Publ., 2362, B1-B19, 1984.

Gleason, J. F., et al., Record low global ozone in 1992, Science, 260, 523-526, 1993.

Godin, S., Etude expérimentale par télédétection laser et modélisation de la distribution verticale d'ozone dans la haute stratosphère, Thèse doctorat, Univ. Paris 6, France, 1987.

Godin, S., G. Mégie, and J. Pelon, Systematic lidar measurements of the stratospheric ozone vertical distribution, Geophys. Res. Lett., 16, 547-550, 1989.

Godin, S., et al., DIAL ozone algorithm intercomparison, Appl. Opt., in press, 2000.

Götz, F. W., A. R. Meetham, and G. M. Dobson, The vertical distribution of ozone in the atmosphere, Proc. Roy. Soc. London, A415, 416-446, 1934.

Guirlet, M., Etude des variations saisonnières et des tendances de l'ozone stratosphérique aux moyennes latitudes de l'hémisphère Nord, Thèse doctorat, Univ. Paris 6, France, 1997.

Harris, N. R. P., et al., Trends in stratospheric and free tropospheric ozone, J. Geophys. Res., 102, 1571-1590, 1997.

Hauchecorne, A., M. L. Chanin, and P. Keckhut, Climatology and trends of the middle atmospheric temperature $(33-37 \mathrm{~km})$ as seen by Rayleigh lidar over the South of France, J. Geophys. Res., 96, 15 297-15 309, 1991.

Hilsenrath, E., W. Attmannspacker, A. Bass, W. Evans, R. Hagemeyer, R. A. Barnes, W. Komhyr, K. Mauersberger, J. Mentall, M. Profitt, D. Robbins, S. Taylor, A. Torres, and E. Weinstock, Results from the balloon ozone intercomparison campaign (BOIC), J. Geophys. Res., 91, 13 137-13 152, 1986.

Hood, L. L., The solar cycle variation of total ozone: dynamical forcing in the lower stratosphere, J. Geophys. Res., 102, 13551370, 1997.
Hood, L. L., and D. A. Zaff, Lower stratospheric stationary waves and the longitude dependence of ozone trends in winter, J. Geophys. Res., 100, 25 791-25 800, 1995.

Hood, L. L., J. L. Jirikowic, and J. P. Mc Cormack, Quasi-decadal variability of the stratosphere: influence of long-term solar ultraviolet variations, J. Atmos. Sci., 50, 3941-3958, 1993.

Jackman, H. C., E. L. Fleming, S. Chandra, D. B. Considine, and J. E. Rosenfield, Past, present, and future modeled ozone trends with comparisons to observed trends, J. Geophys. Res., 101, 28 753-28 767, 1996

Keating, G. M., G. P. Brasseur, L. S. Chiou, and N. C. Hsu, Estimating 11-year solar UV variations using 27-day response as a guide to isolate trends in total column ozone, Adv. Space Res., 14, 199-209, 1994a.

Keating, G. M., L. S. Chiou, and N. C. Hsu, Coupling between middle atmosphere trend estimates and solar effects in ozone vertical structure, Adv. Space Res., 14, 201-209, 1994b.

Keckhut, P., A. Hauchecorne, and M. L. Chanin, Mid-latitude long-term variability of the middle atmosphere: trends and cyclic episodic changes, J. Geophys. Res., 100, 18 887-18 897, 1995.

Keckhut, P., F. J. Schmidlin, A. Hauchecorne, and M. L. Chanin, Stratospheric and mesospheric cooling trend estimated from U.S. rocketsondes at low latitude stations $(8 \mathrm{~S}-34 \mathrm{~N})$ taking into account instrumental changes and natural variability, J. Atmos. Terr. Phys., 61, 447-459, 1999.

Komhyr, W. D., R. D. Grass, and R. K. Leonard, Dobson spectrometer 83: a standard for total ozone measurements, 1962-1987, J. Geophys. Res., 94, 9847-9861, 1989.

Komhyr, W. D., R. A. Barnes, G. B. Brothers, J. A. Lathrop, and D. P. Opperman, Electrochemical concentration cell ozonesonde performance evaluation during STOIC 1989, J. Geophys. Res., 100, 9231-9244, 1995.

Kurylo, M. J., and S. Solomon, Network for the detection of stratospheric changes, Rep. EEU, NASA, Greenbelt, Md., 1990.

Lacoste, A. M., Observations de l'ozone dans la stratosphère: validation et mise en place d'une base de données obtenues par sondage laser: étude climatologique et de tendance de l'ozone stratosphérique à l'Observatoire de Haute-Provence, Thèse doctorat, Univ Paris 6, France, 1994.

La Noë de, J., et al., Remote and ground-based measurements of ozone profiles during the MAP/GLOBUS 1983 campaign, Planet. Space Sci., 5, 547-562, 1987.

Logan, J. A., Trends in the vertical distribution of ozone: an analysis of ozonesonde data, J. Geophys. Res., 99, $25553-$ 25 585, 1994.

Mateer, C. L., and J. J. DeLuisi, A new Umkehr inversion algorithm, Atm. Terr. Phys., 54, 537-556, 1992.

Mc Gee, T. J., M. Gross, R. Ferrare, W. Heaps, and U. Singh, Raman dial measurements of stratospheric ozone in the presence of volcanic aerosols, Geophys. Res. Lett., 20, 955-958, 1993.

Mc Gee, T. J., P. Newman, M. Gross, U. Singh, S. Godin, A. M. Lacoste, and G. Mégie, Correlation of ozone loss with the presence of volcanic aerosols, Geophys. Res. Lett., 21, 28012804, 1994.

McPeters, R. D., T. Miles, L. E. Flynn, C. G. Wellemeyer, and J. M. Zawodny, Comparison of SBUV and SAGE II ozone profiles: implications for ozone trends, J. Geophys. Res., 99, 20 513-20 524, 1994.

McPeters, R. D., A. J. Krueger, and P. K. Bhartia, Spectral analyses, climatology, and interannual variability of Nimbus-7 TOMS version 6 total column ozone, Bull. Am. Meteorol. Soc., 77, 353-357, 1996.

Mégie, G., G. Ancellet, and J. Pelon, Lidar measurements of ozone vertical profiles, Appl. Opt., 24, 3454-3463, 1985.

Miller, A. J., et al., Comparisons of observed ozone trends and solar effects in the stratosphere through examination of groundbased Umkehr and combined solar backscattered ultraviolet (SBUV) and SBUV 2 satellite data, J. Geophys. Res., 101, 90179021, 1996. 
Newchurch, M. J., and D. M. Cunnold, Aerosol effect on Umkehr ozone profiles using Stratospheric Aerosol and Gas Experiment II measurements, J. Geophys. Res., 99, 1383-1388, 1994.

Newchurch, M. J., D. M. Cunnold, and H. J. Wand, Stratospheric Aerosol and Gas Experiment II - Umkehr ozone profile comparisons, J. Geophys. Res., 100, 14 029-14 042, 1995.

Pelon, J., and G. Mégie, Ozone monitoring in the troposphere and lower stratosphere - evaluation and operation of a groundbased lidar station, J. Geophys. Res., 87, 4947-4955, 1982.

Pelon, J., S. Godin, and G. Mégie, Upper stratospheric $(30-50 \mathrm{~km})$ lidar observations of the ozone vertical distribution, J. Geophys. Res., 91, 8667-8671, 1986.

Pommereau, J. P., and F. Goutail, $\mathrm{O}_{3}$ and $\mathrm{NO}_{2}$ ground-based measurements by visible spectrometry during Arctic winter and spring 1988, Geophys. Res. Lett., 8, 891-894, 1988.

Portmann, R. W., S. Solomon, R. R. Garcia, L. W. Thomason, L. R. Poole, and M. P. McCormick, Role of aerosol variations in anthropogenic ozone depletion in the polar regions, J. Geophys. Res., 101, 22 991-23 006, 1996.

Press, W. H., P. Flannery, S. A. Teukolsky, and W. T. Vetterling, Numerical recipes, the art of scientific computing, 2nd edn., Cambridge Univ. Press, 1989.

Randel, W. J., and F. Wu, Isolation of the ozone QBO in SAGE-II data by singular value decomposition, J. Atmos. Sci., 53, 25462559, 1996.

Simon, P., G. Roland, S. Godin, J. de La Noe, H. Jager, R. Peter, G. Visconti, and C. Brogniez, European Stratospheric Monitoring Stations in the Alps II (ESMOS/ALPS II), in European stratospheric ozone research 1996-1997, Air Pollut. Res. Rep., 56, 27-30, 1997.

Sitnov, S. A., Vertical structure of the extratropical quasi-biennal oscillation in ozone, temperature, and wind derived from ozonesonde data, J. Geophys. Res., 101, 12 855-12 866, 1996.

Smit, H. G. J., and D. Kley, JOSIE: the 1996 WMO international intercomparison of ozonesondes under quasi-flight conditions in the environmental simulation chamber at Jülich, $W M O$ IGAC-Rep, WMO Global Atmos. Watch Rep. Ser., 130, Tech. Doc. 926, WMO, Geneva, 1998.

Solomon, S., R. W. Portmann, R. R. Garcia, L. W. Thomason, L. R. Poole, and M. P. Mc Cormick, The role of aerosol variations in anthropogenic ozone depletion at northern mid-latitudes, J. Geophys. Res., 101, 6713-6727, 1996.
Solomon, S., R. W. Portmann, R. R. Garcia, W. Randel, F. Wu, R. Nagatani, J. Gleason, L. Thomason, L. R. Poole, and M. P. McCormick, Ozone depletion at mid-latitudes: coupling of volcanic aerosols and temperature variability to anthropogenic chlorine, Geophys. Res. Lett., 25, 1871-1874, 1998.

SPARC-IOC, Assessment of trends in the vertical distribution of ozone, SPARC Rep., 1, 1998.

Staehelin, J., R. Kegel, and N. R. P. Harris, Trend analysis of the homogenized total ozone series of Arosa (Switzerland), 19261996, J. Geophys. Res., 103, 8389-8399, 1998.

Stolarski, R. S., P. Bloomfield, R. McPeters, and J. Herman, Total ozone trends deduced from Nimbus 7 TOMS data, Geophys. Res. Lett., 18, 1015-1018, 1991.

Stolarski, R., R. Bojkov, L. Bishop, C. Zerefos, J. Staehelin, and J. Zawodny, Measured trends in stratospheric ozone, Science, 256, 342-349, 1992.

Thomason, L. W., and L. R. Poole, A global climatology of stratospheric aerosol surface area density deduced from Stratospheric Aerosol and Gas Experiment II measurements: 1984 1994, J. Geophys. Res., 102, 8967-8976, 1997.

Tie, X. X., G. P. Brasseur, B. Briegleb, and C. Granier, Twodimensional simulation of Pinatubo aerosol and its effect on stratospheric ozone, J. Geophys. Res., 99, 20 545-20 562, 1994.

Vialle, J., Informations et historique sur les sondages ballons dans le Sud de la France de 1976 a 1997, Internal Rep. CNRS/IPSL, 1997.

WMO, Report of the meetings of experts on sources of errors in detection of ozone trends, in World Meteorological Organization ozone project, Rep., 12, WMO Ozone Secretariat, Toronto, 1982.

WMO, Report of the International Ozone Trends Panel: 1988, in Global ozone research and monitoring project, Rep., 18, WMO Ozone Secretariat, Geneva, Switzerland, 1988.

WMO, Scientific assessment of ozone depletion: 1991, in Global ozone research and monitoring project, Rep., 25, WMO Ozone Secretariat, Geneva, Switzerland, 1991.

WMO, Scientific assessment of ozone depletion: 1994, in Global ozone research and monitoring project, Rep., 37, WMO Ozone Secretariat, Geneva, Switzerland, 1994.

WMO, Scientific assessment of ozone depletion: 1998, in Global ozone research and monitoring project, Rep., 44, WMO Ozone Secretariat, Geneva, Switzerland, 1998. 